\title{
Menjaga Mutu Pendidikan di Tengah Pandemi Covid-19: Studi Pembelajaran Online di Universitas Islam Negeri Walisongo Semarang
}

\author{
${ }^{1}$ Kurnia Muhajarah, ${ }^{2}$ Silvia Riskha Fabriar \\ 1,2Fakultas Dakwah dan Komunikasi, UIN Walisongo Semarang, Indonesia, \\ kurniamuhajarah@walisongo.ac.id, silviariskhaf@walisongo.ac.id
}

\section{ARTICLE INFO}

Article History:

Received : 11-03-2020

Revised : 05-05-2020

Accepted : 10-05-2020

Online : 30-05-2020

Keywords:

Pembelajaran Online;

Covid-19;

Platform

E-Learning

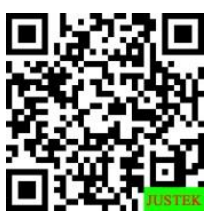

\begin{abstract}
Abstract: Circular of the Chancellor of UIN Walisongo Semarang Number B-1727/Un.10.0/R/HM.00/3/2020 concerning Regulations for Service Activities and Academic Activities in Preventing the Spread of Covid-19 has stipulated provisions related to academic activities, one of this which is by implementing online learning. This research is a descriptive qualitative study which aims to obtain an overview of online learning during the Covid-19 pandemic at the Faculty of Da'wa and Communication. The subjects of this study were 1.138 lecturers and students of the Faculty of Da'wa and Communication. Data is collected through the Google Form platform, the link of which is shared through the WhatsApp platform. Data analysis was performed using interactive analysis techniques Miles \& Huberman. The results show that online learning makes students feel more comfortable to ask questions and express their opinions compared to face-to-face lectures. The effectiveness of online learning by talking about internet services and low-cost e-learning platforms. This is evidenced by the Whatsapp Group (WAG) platform in the first place followed by Line, Google Classroom, Google Meet, Zoom, then platforms other than this, and Webex in the last place.
\end{abstract}

Abstrak: Edaran Rektor UIN Walisongo Semarang Nomor B1727/Un.10.0/R/HM.00/3/2020 perihal Pengaturan Kegiatan Pelayanan dan Kegiatan Akademik dalam Pencegahan Penyebaran Covid-19 telah menetapkan ketentuan terkait kegiatan akademik, salah satunya yakni dengan melaksanakan pembelajaran online. Penelitian ini merupakan penelitian kualitatif deskriptif yang bertujuan untuk memperoleh gambaran pembelajaran online masa pandemi Covid-19 di Fakultas Dakwah dan Komunikasi,.Subjek penelitian ini adalah dosen dan mahasiswa Fakultas Dakwah dan Komunikasi sejumlah 1.138 responden. Data dikumpulkan melalui platform Google Form yang tautannya disebarkan melalui platform WhatsApp. Analisis data dilakukan menggunakan teknik analisis interaktif Miles \& Huberman. Hasil penelitian menunjukkan bahwa pembelajaran online membuat mahasiswa merasa lebih nyaman untuk bertanya dan mengemukakan pendapatnya dibanding perkuliahan tatap muka, Efektivitas pembelajaran online berkaitan dengan ketersediaan layanan internet dan platform e-learning berbiaya rendah. Hal ini terbukti dengan platform Whatsapp Group (WAG) menempati urutan pertama diikuti Line, Google Classroom, Google Meet, Zoom, kemudian platform selain ini, dan Webex menempati urutan terakhir. 


\section{A. LATAR BELAKANG}

Covid-19 merupakan penyakit dengan tingkat penyebaran yang tergolong cepat. Penyakit ini disebabkan oleh virus Corona yang secara khusus menyerang sistem pernafasan manusia (Rothan and Byrareddy 2020). Pengendalian penyakit ini dilakukan dengan meminimalisir kontak antara orang yang terinfeksi dengan orang-orang yang rentan ditulari (Caley, Philip, and McCracken 2008). Menjaga jarak untuk mengurangi kontak fisik yang berpotensi menularkan penyakit dikenal dengan istilah social distancing (Bell et al. 2006b). Melaksanakan social distancing dianggap sebagai sebuah tindakan yang perlu guna menekan penyebaran Covid-19 (Stein 2020).

Berbagai usaha untuk mengurangi penyebaran Covid-19 di lingkungan kampus, UIN Walisongo Semarang, berdasarkan pada Edaran Rektor Nomor B1727/Un.10.0/R/HM.00/3/2020 tertanggal 24 Maret 2020, perihal Pengaturan Kegiatan Pelayanan dan Kegiatan Akademik dalam Pencegahan Penyebaran Covid-19. Implikasi dari surat edaran ini adalah kebijakan untuk melaksanakan melaksanakan pembelajaran online, yakni pembelajaran dari rumah untuk mahasiswa, WFH (Work From Home) dan WFO (Work from Office) berbatas waktu kerja bagi para pejabat dan dosen muda. Hal ini, bertujuan untuk membatasi kerumunan dan interaksi di dalam kampus.

Menurut data UNESCO, sebagaimana dilansir oleh Agus Purwanto (2020), setidaknya ada 290,5 juta siswa dan mahasiswa di seluruh dunia yang aktivitas belajarnya menjadi terganggu akibat sekolah dan perguruan tinggi yang ditutup. Setidaknya, terdapat 65 perguruan tinggi di Indonsesia yang menyelenggarakan pembelajaran dari rumah untuk mencegah penyebaran Covid-19 (CNN Indonesia 2020; Muharam 2020). Kewaspadaan dan pencegahan penyebaran infeksi Covid-19 di lingkungan kampus, tentunya mengubah pembelajaran tatap muka menjadi pembelajaran online (Yandwiputra 2020; Purandina 2020).

Pembelajaran online dilakukan menggunakan jaringan internet memungkinkan dosen dan mahasiswa untuk berada di tempat yang berbeda selama proses pembelajaran (Darmalaksana et al. 2020). Dosen dapat membuat materi ajar yang dapat diakses oleh mahasiswa secara online dari mana saja dan kapan saja (Bell et al. 2006a; Andini 2020). Pembelajaran yang dilaksankan menggunakan teknologi internet memungkinkan adanya interaksi melalui web, dimana dosen dan mahasiswa berada di tempat yang benar-benar terpisah (Arzayeva et al. 2015). Penerapan pembelajaran online memungkinkan mahasiswa untuk mengikuti perkuliahan dari rumah masing-masing (Aisa and Lisvita 2020; Jatmoko and Faizun 2020; Andini 2020). Mereka dapat mengakses bahan ajar dan mengirimkan tugas yang diberikan oleh dosen tanpa harus datang ke kampus. Sayangnya, tidak semua daerah memiliki konektivitas jaringan internet yang baik (Puspitorini 2020; Salsabila et al. 2020)

Pembelajaran online yang sifatnya mendadak di tengah minimnya kesiapan pemerintah dan masyarakat, menjadi salah satu pertanyaan dalam penelitian, disamping mengukur bagaimana efektivitas penggunaan platform pembelajarannya. Untuk inilah, penelitian ini wajib untuk dicari akar dan solusinya. Penelitian ini bertujuan untuk memperoleh gambaran yang jelas mengenai pembelajaran online yang dilaksanakan di Fakultas Dakwah dan Komunikasi selama pandemi Covid-19. 


\section{B. METODE PENELITIAN}

Penelitian ini merupakan penelitian kualitatif deskriptif. Penelitian ini dilakukan di akhir semester Genap 2019-2020, yakni dari rentang April akhir hingga awal Mei 2020. Subjek penelitian ini adalah dosen dan mahasiswa Fakultas Dakwah dan Komunikasi dari seluruh prodi yang ada. Jumlah responden adalah 1.138 orang. Survei dengan wawancara by phone, dengan sampling acak, dilakukan oleh peneliti sebelum penelitian dimulai. Adapun data dikumpulkan melalui aplikasi Google Form, yang tautannya disebarkan melalui aplikasi WhatsApp.

Pelaksanaan penelitian ini menggunakan question sheet dari LPM (Lembaga Penjamin Mutu) UIN Walisongo yang dilaksanakan oleh tim GPM (Gugus Penjamin Mutu) Fakultas, dan GKM (Gugus Kendali Mutu) masing-masing Prodi. Aspek-aspek yang ditanyakan dalam question sheet, diantaranya: (1) Platform e-Learning yang digunakan; (2) Efektivitas penggunaan platform sesuai poin 1; (3) Saran terkait penyempurnaan aplikasi e-Learning Walisongo. Namun poin (3), tidak penulis tulis di sini. Analisis data penelitian dilakukan menggunakan model analisis Miles \& Huberman (1994) yang terdiri dari empat tahapan, yaitu reduksi data, display data, serta penarikan dan verifikasi kesimpulan.

\section{HASIL DAN PEMBAHASAN}

\section{Pemilihan dan Penggunaan Platform E-Learning}

Laura, et al. (2016:1) menjelaskan bahwa peningkatan jumlah pengguna platform teknologi dalam masyarakat merupakan sebuah kenyataan. Pada satu dekade terakhir jumlah pengguna layanan telepon pintar (smartphone) di dunia meningkat sangat signifikan. Data hasil pra penelitian menunjukkan bahwa meskipun ada mahasiswa yang belum memiliki laptop, tapi hampir semua mahasiswa telepon pintar. Hasil survei yang dilaksanakan pada awal penelitian, berdasarkan survei acak by phone, dari $10 \%$ dari total 1.138 responden menunjukkan bahwa 73 responden menyatakan memiliki laptop dan telepon pintar, sementara 41 sisanya menyatakan hanya memiliki telepon pintar.

Kegiatan monitoring dan evaluasi terhadap pembelajaran, dalam hal ini pemilihan dan penggunaaan e-learning diadakan di awal dan akhir perkuliahan. Objek kegiatan ini meliputi 5 prodi S1 dan 1 prodi S2. Keenam prodi ini adalah Prodi Komunikasi dan Penyiaran Islam (KPI), Prodi Bimbingan Penyuluhan Islam (BPI), Prodi Manajeman Dakwah (MD), Prodi Pengembangan Masyarakat Islam (PMI), Prodi Manasik Haji dan Umrah (MHU), dan Prodi S2 Komunikasi dan Penyiaran Islam (KPI). Jumlah keseluruhan responden yang mengisi kuesioner sebanyak 1.138 responden, terdiri dari 349 (30\%) responden dari Bimbingan Penyuluhan Islam (BPI), $243(21.4 \%)$ responden dari prodi Manajemen Dakwah (MD), kemudian 208 (18.3\%) responden dari prodi Pengembangan Masyarakat Islam (PMI), sedangkan $202(17.8 \%)$ responden dari prodi Manajemen Haji dan Umroh (MHU), 130 (11.5\%) responden dari prodi Komunikasi dan Penyiaran Islam (S1. KPI), sementara dari Prodi S2 Komunikasi dan Penyiaran Islam tidak memberikan respon (0\%).

Selanjutnya, untuk mengetahui pemilihan dan penggunaan aplikasi yang paling banyak digunakan selama pembelajaran online, dari gambar 2, dapat diketahui bahwa ada lima (5) aplikasi yang paling sering digunakan oleh seluruh responden baik dari prodi KPI, BPI, MD, 
PMI dan MHU yaitu, Whatsapp Group (WAG) 82,3\%. menempati urutan kedua adalah $e$ learningwalisongo sebanyak $61.9 \%$. Ada aplikasi Line sebesar $54.3 \%$. Sementara penggunaan Google Clasroom, kurang dari $40 \%$ responden. Responden juga menggunakan aplikasi lainnya, seperti Google Meet, Zoom, Webex, Youtube, Edmodo, Jitse, ada juga yang menggunakan kombinasi.
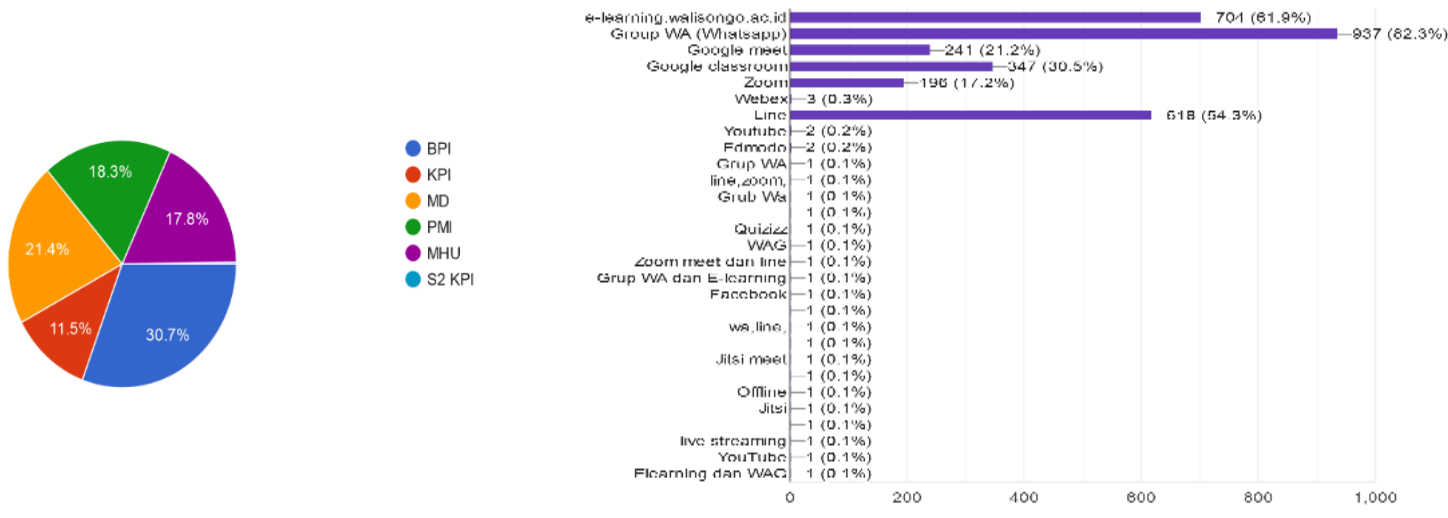

Gambar 1. Jumlah Responden dalam Prosentase

Gambar 2. Grafik Pemilihan dan Penggunaan Platform E-Learning

Terdapat satu temuan menarik dalam penelitian ini. Mahasiswa merasa lebih nyaman untuk bertanya dan mengemukakan pendapat dalam forum perkuliahan yang dilaksanakan secara online. Belajar dari rumah membuat mereka tidak merasakan tekanan sebaya yang biasa mereka rasakan ketika belajar bersama teman di dalam perkuliahan yang dilaksanakan secara tatap muka. Ketidakhadiran dosen secara fisik juga membuat mereka tidak merasa canggung dalam mengemukakan pendapat.

\section{Efektivitas Penggunaan Platform e-Learning}

Pembelajaran online yang diberlakukan di Fakultas Dakwah dan Komunikasi UIN Walisongo Semarang sebagai usaha untuk menekan penyebaran Covid-19. Pembelajaran online menggunakan aplikasi serta layanan kelas virtual yang dapat diakses melalui web menggunakan jaringan internet. Secara umum, mahasiswa merasa puas mengenai fleksibilitas pelaksanaan perkuliahan. Mahasiswa tidak tertekan oleh waktu karena mereka dapat mengatur sendiri jadwal dan tempat dimana mereka ingin mengikuti perkuliahan. Melalui pembelajaran secara online, dosen memberikan kuliah melalui kelas-kelas virtual yang dapat diakses dimanapun dan kapanpun.

Pada pengujian selanjutnya, Lembaga Penjaminan Mutu (2020) memberikan instrumen pada responden untuk memberikan penilaian (scoring) untuk mengukur efektifitas sarana aplikasi e-learning yaitu: Skor 5, sangat efektif (bila kondisi sinyal dan aplikasi bisa diakses dengan baik oleh semua mahasiswa pengambil Mata Kuliah (MK), atau tidak ada keluhan sama sekali dari mahasiswa dan dosen). Skor 4, efektif (bila kondisi sinyal dan aplikasi bisa diakses dengan baik oleh hampir semua mahasiswa pengambil MK, atau ada keluhan dari dosen). Skor 3, cukup efektif (bila kondisi sinyal dan aplikasi bisa diakses dengan baik oleh separoh atau lebih dari mahasiswa pengambil Mata Kuliah, atau terdapat keluhan dari dosen). Skor 2, kurang efektif (bila kondisi sinyal dan aplikasi kurang bisa diakses dengan baik oleh sebagian besar mahasiswa pengambil Mata Kuliah, atau terdapat keluhan dari dosen). Skor 1, sangat kurang efektif (bila kondisi sinyal dan aplikasi kurang bisa diakses dengan baik oleh 
semua mahasiswa pengambil Mata Kuliah, atau terdapat keluhan dari dosen dan atau dari 76 s/d 100 persen mahasiswa pengambil MK).

Berikut ini adalah penilaian penggunaan varian platform e-learning dan efektivitasnya.

a. Penilaian Efektivitas Platform E-Learning Walisongo

UIN Walisongo Semarang memiliki platform online-nya, yakni e-learning Walisongo. E-learning.walisongo.ac.id sebagai salah satu metode perkuliahan daring yang digunakan dalam proses pembelajaran. Terdapat 1122 responden yang menjawab pertanyaan ini yang kemudian dilakukan penilaian melalui Google Form. Dari 1122 responden, terdapat $7.7 \%$ responden yang menyatakan bahwa E-Learning Walisongo sudah sangat efektif; $28.6 \%$ responden menyatakan efektif; $38.7 \%$ menyatakan cukup efektif; $17,4 \%$ menyatakan kurang efektif; dan 7,7\% menyatakan sangat kurang efektif.

b. Penilaian Efektivitas Platform Whatsapp Group (WAG)

Dari 1123 responden, terdapat 53,5\% responden yang menyatakan bahwa Grup WhatsApp sudah sangat efektif; $32,3 \%$ responden menyatakan efektif; $11,2 \%$ menyatakan cukup efektif; 2,1\% menyatakan kurang efektif; dan $0,8 \%$ menyatakan sangat kurang efektif.

c. Penilaian Efektivitas Platform Google Meet

Dari 1018 responden, terdapat $12 \%$ responden yang menyatakan bahwa aplikasi Google Meet sudah sangat efektif; 31,6\% responden menyatakan efektif; 37,3\% menyatakan cukup efektif; $14,2 \%$ menyatakan kurang efektif; dan 4,8\% menyatakan sangat kurang efektif.

\section{d. Penilaian Efektivitas Platform Google Classroom}

Dari 1054 responden, terdapat $18,8 \%$ responden yang menyatakan bahwa aplikasi Google Meet sudah sangat efektif; 38\% responden menyatakan efektif; 33,5\% menyatakan cukup efektif; 6,9\% menyatakan kurang efektif; dan 2,8\% menyatakan sangat kurang efektif.

\section{e. Penilaian Efektivitas Platform Zoom}

Terdapat 1019 responden, 5,8\% responden yang menyatakan bahwa aplikasi aplikasi Zoom sudah sangat efektif; 21,3\% responden menyatakan efektif; 33,5\% menyatakan cukup efektif; 25,9\% menyatakan kurang efektif; dan 13,5\% menyatakan sangat kurang efektif.

\section{f. Penilaian Efektivitas Platform Webex}

Sebanyak 945 responden memberikan penilainnya. 1,5\% responden yang menyatakan bahwa aplikasi aplikasi Webex sudah sangat efektif; 8,3\% responden menyatakan efektif; 34,7\% menyatakan cukup efektif; 30,8\% menyatakan kurang efektif; dan 24,8\% menyatakan sangat kurang efektif.

\section{g. Penilaian Efektivitas Platform Line}

Sebanyak 1080 responden, terdapat $18,7 \%$ responden yang menyatakan bahwa aplikasi Line sudah sangat efektif; 36,5\% responden menyatakan efektif; 30,1\% menyatakan cukup efektif; $10,4 \%$ menyatakan kurang efektif; dan 4,4\% menyatakan sangat kurang efektif.

\section{h. Penilaian Efektivitas Selain Platform di Atas}

Terdapat 952 responden. 7,5\% responden yang menyatakan bahwa aplikasi selain tersebut diatas sudah sangat efektif; 22,5\% responden menyatakan efektif; 42,6\% 
menyatakan cukup efektif; 16,6\% menyatakan kurang efektif; dan 10,8\% menyatakan sangat kurang efektif.

Berdasarkan semua pemaparan di atas, maka dapat disimpulkan bahwa platform Whatsapp Group (WAG) menempati urutan pertama dari sisi efektifitas proses pembelajaran online, diikuti platform Line, Google Classroom, aplikasi Google Meet, aplikasi Zoom Us, aplikasi selain tersebut di atas dan aplikasi Webex menempati urutan terakhir.

Pembelajaran online memiliki cerita dan tantangan tersendiri. Salah satunya adalah ketersediaan layanan internet. Hasil penelitian menunjukkan bahwa sebagian besar mahasiswa mengakses internet menggunakan layanan selular, sementara sebagian kecilnya menggunakan layanan WiFi. Akibatnya, karena tidak semua wilayah mendapatkan sinyal seluler yang memadai, membuat mahasiswa terkadang terlambat mendapatkan informasi perkuliahan dan mengumpulkan tugas kuliah. Tantangan lain yang harus dihadapi adalah kendala biaya. mahasiswa menyatakan bahwa untuk mengikuti pembelajaran secara online, mereka harus mengeluarkan biaya lebih untuk membeli kuota data internet. Menurut mahasiwa, pembelajaran yang dilaksanakan dalam bentuk konferensi video menghabiskan kuota yang sangat banyak, sementara diskusi online melalui applikasi pesan instan tidak membutuhkan banyak kuota.

\section{SIMPULAN DAN SARAN}

Pertama, pembelajaran online membuat mahasiswa merasa lebih nyaman untuk bertanya dan mengemukakan pendapatnya dibanding perkuliahan tatap muka, Pembelajaran online membuat mahasiswa tidak merasakan tekanan sebaya yang biasa mereka rasakan ketika belajar tatap muka. Kedua, efektivitas pembelajaran online berkaitan dengan ketersediaan layanan internet dan platform e-learning berbiaya rendah. Hal ini masih menjadi idaman bagi dosen dan mahasiswa. Hal ini terbukti dengan platform Whatsapp Group (WAG) menempati urutan pertama dari sisi efektifitas proses pembelajaran online, diikuti platform Line, lalu Google Classroom,Google Meet, Zoom Us, kemudian aplikasi selain tersebut di atas, dan Webex menempati urutan terakhir.

Terkait dengan pembiayaan dan sarana internet, penulis menyarankan agar pemerintah lebih sigap menyikapi hal ini. Bantuan kuota Pembelajaran Jarak Jauh (PJJ) oleh pemerintah, sangat membantu, walau jumlah bantuan kuota sebesar $10 \mathrm{MB}$ masih sangat minim bagi dosen dan mahasiswa. Adanya pandemi Covid-19, menjadi sarana pemerintah bersama sektor swasta dalam membangun provider lebih massive di seluruh pelosok Indonesia.

\section{REFERENSI}

Aisa, A, and L Lisvita. 2020. "Penggunaan Teknologi Informasi Dalam Pembelajaran Online Masa Covid-19." JoEMS (Journal of Education and Management ... 3(4).

Andini, N F. 2020. "Dampak Pembelajaran Daring Bagi Mahasiswa Masa Pandemi Covid-19." Academia.Edu (2020).

Arzayeva, Maiya, Kalzhan Rakhimzhanov, Aliya Abdrahmanova, and Ulan Umitkaliev. 2015. "Special Aspects of Distance Learning in Educational System." Anthropologist 22(3): 449-54.

Bell, David et al. 2006a. "Nonpharmaceutical Interventions for Pandemic Influenza, International Measures." Emerging Infectious Diseases 12(1): 81-87.

-__. 2006b. "Nonpharmaceutical Interventions for Pandemic Influenza, National and Community Measures." Emerging Infectious Diseases 12(1): 88-94. 
Caley, Peter, David J. Philp, and Kevin McCracken. 2008. "Quantifying Social Distancing Arising from Pandemic Influenza." Journal of the Royal Society Interface 5(23): 631-39.

CNN Indonesia. (2020). 65 kampus kuliah dari rumah, sultan yogya ragukan efektivitas. Retrieved from https://www.cnnindonesia.com/nasional/2020031611070720483756/65-kampus-kuliah-dari-rumah-sultan-yogya-ragukan-efektivitas

Darmalaksana, Wahyudin, R. Yuli Ahmad Hambali, Ali Masrur, and Muhlas. 2020. "Analisis Pembelajaran Online Masa WFH Pandemic Covid-19 Sebagai Tantangan Pemimpin Digital Abad 21." Karya Tulis Ilmiah (KTI) Masa Work From Home (WFH) Covid-19 UIN Sunan Gunung Djati Bandung Tahun 2020 1(1): 1-12.

Enriquez, M. A. S. (2014). Students 'perceptions on the effectiveness of the use of edmodo as a supplementary tool for learning. DLSU Research Congress. https://doi.org/10.1017/CB09781107415324.004

Iftakhar, S. (2016). GOOGLE CLASSROOM: WHAT WORKS AND HOW? Journal of Education and Social Sciences.

Jatmoko, Dwi, and Mahfudz Faizun. 2020. "Persepsi Mahasiswa Terhadap Pelayanan Pembelajaran Online Di Masa Pandemi Covid-19." Jurnal Pendidikan Surya Edukasi (JPSE) 6(1): 104-13.

Korucu, A. T., \& Alkan, A. (2011). Differences between m-learning (mobile learning) and elearning, basic terminology and usage of m-learning in education. Procedia - Social and Behavioral Sciences. https://doi.org/10.1016/j.sbspro.2011.04.029

Kumar, V., \& Nanda, P. (2018). Social media in higher education. International Journal of Information and Communication Technology Education. https://doi.org/10.4018/ijicte.2019010107

Kwon, M., Lee, J. Y., Won, W. Y., Park, J. W., Min, J. A., Hahn, C., ... Kim, D. J. (2013). Development and Validation of a Smartphone Addiction Scale (SAS). PLoS ONE. https://doi.org/10.1371/journal.pone.0056936

Laura, B. P., Anabela P., Lina, C., Juan, A. J. M. (2016). Learning with mobile technologies students behavior. Proceeding of Computers in Human Behavior. P. 1-9. doi:10.1016/j.chb.2016.05.027.

Lembaga Penjaminan Mutu UIN Walisongo. (2020). Instrumen Monitoring dan Evaluasi Sarana Aplikasi Perkuliahan Online/ Daring (E-Learning)

Miles, M. B., \& Huberman, M. (1994). Qualitative Data Analysis Second Edition. SAGE Publications.

Milman, N. B. (2015). Distance education. In International Encyclopedia of the Social \& Behavioral Sciences: Second Edition. https://doi.org/10.1016/B978-0-08-097086-8.920014

Moore, J. L., Dickson-Deane, C., \& Galyen, K. (2011). E-Learning, online learning, and distance learning environments: Are they the same? Internet and Higher Education. https://doi.org/10.1016/j.iheduc.2010.10.001

Muharam, Suhari. 2020. "DILEMA PEMBELAJARAN DI MASA PANDEMI." Osteoarthritis and Cartilage 28(2): 1-43.

Purandina, I Putu Yoga. 2020. "Pendidikan Karakter Tumbuh Selama Pandemi Covid-19.” COVID19: Perspektif Pendidikan.

Puspitorini, Ferawaty. 2020. "Strategi Pembelajaran Di Perguruan Tinggi Pada Masa Pandemi Covid-19." Jurnal Kajian Ilmiah 1(1): 99-106.

Purwanto, Agus, et.al. (2020). "Studi Eksploratif Dampak Pandemi Covid-19 terhadap Proses Pembelajaran Online di Sekolah Dasar", EduPsyCouns Journal, Vol. 2. Nomor 1.

Rothan, Hussin A., and Siddappa N. Byrareddy. 2020. "The Epidemiology and Pathogenesis of Coronavirus Disease (COVID-19) Outbreak." Journal of Autoimmunity 109.

Salsabila, Unik Hanifa et al. 2020. "PERAN TEKNOLOGI DALAM PEMBELAJARAN DI MASA PANDEMI COVID-19." Al-Mutharahah: Jurnal Penelitian dan Kajian Sosial Keagamaan 17(2): 188-98.

Stein, Richard A. 2020. "COVID-19 and Rationally Layered Social Distancing." International Journal of Clinical Practice 74(7). 
Sicat, A. S. (2015). Enhancing college students' proficiency in business writing via schoology. International Journal of Education and Research.

So, S. (2016). Mobile instant messaging support for teaching and learning in higher education. Internet and Higher Education. https://doi.org/10.1016/j.iheduc.2016.06.001

Zhang, D., Zhao, J. L., Zhou, L., \& Nunamaker, J. F. (2004). Can e-learning replace classroom learning? Communications of the ACM. https://doi.org/10.1145/986213.986216

Yandwiputra, A. R. (n.d.). Kuliah Jarak Jauh karena Virus Corona, UI: Bukan Lockdown. Retrieved from https://metro.tempo.co/read/1319537/kuliah-jarak-jauh-karena-viruscorona-uibukan-lockdown

WHO. (n.d.). (2020). Points of entry and mass gatherings. Retrieved March 28 from https://www.who.int/emergencies/diseases/novel-coronavirus2019/technical guidance/ points-of-entry-and-mass-gatherings 